University of Wollongong

Research Online

Faculty of Engineering and Information

Faculty of Engineering and Information

Sciences - Papers: Part A

Sciences

1995

\title{
The formation of ternary compound Fe3Mo3C by ball milling
}

L M. Di

Australian National University

Andrzej Calka

University of Wollongong, acalka@uow.edu.au

Z L. Li

Australian National University, zli@pku.edu.cn

J S. Williams

Australian National University

Follow this and additional works at: https://ro.uow.edu.au/eispapers

Part of the Engineering Commons, and the Science and Technology Studies Commons

Research Online is the open access institutional repository for the University of Wollongong. For further information contact the UOW Library: research-pubs@uow.edu.au 


\title{
The formation of ternary compound Fe3Mo3C by ball milling
}

\author{
Abstract \\ Ball milling of $\mathrm{Mo}$ in nitrogen and ammonia gases has been studied. After heating, the formation of an \\ intriguing ternary compound, $\mathrm{Fe}_{3} \mathrm{Mo}_{3} \mathrm{C}_{1-x}$, was observed as a result of $\mathrm{Fe}$ (and $\mathrm{C}$ ) contamination from the \\ milling apparatus. For a comparison, mechanical alloying of $\mathrm{Fe}-\mathrm{Mo}-\mathrm{C}$ powders with a stoichiometric \\ composition of $\mathrm{Fe}_{3} \mathrm{Mo}_{3} \mathrm{C}$ was also performed and again an $\mathrm{Fe}-\mathrm{Mo}-\mathrm{C}$ alloy was obtained after \\ milling. Thermal analysis shows a single transition peak for the formation of both the $\mathrm{Fe}_{3} \mathrm{Mo}_{3} \mathrm{C}$ phase in \\ the latter case and also for $\mathrm{Fe}_{3} \mathrm{Mo}_{3} \mathrm{C}_{1-x}$ formed as a result of contamination from the mill. The lattice \\ parameter for the $\mathrm{Fe}_{3} \mathrm{Mo}_{3} \mathrm{C}_{1-x}$ phase obtained by Mo-gas reaction is smaller than for the $\mathrm{Fe}_{3} \mathrm{Mo}_{3} \mathrm{C}$ phase \\ obtained by mechanical alloying of stoichiometric $\mathrm{Fe}-\mathrm{Mo}-\mathrm{C}$ powders. It is suggested that, in the \\ $\mathrm{Fe}_{3} \mathrm{Mo}_{3} \mathrm{C}_{1-x}$ phase produced by milling of Mo in gases, a high concentration of $\mathrm{C}$ vacancies exists.

\section{Keywords} \\ ternary, milling, ball, compound, formation, fe3mo3c

\section{Disciplines} \\ Engineering | Science and Technology Studies

\section{Publication Details} \\ Di, L. M., Calka, A., Li, Z. L. \& Williams, J. S. (1995). The formation of ternary compound Fe3Mo3C by ball \\ milling. Journal of Applied Physics, 78 (6), 4118-4122.
}




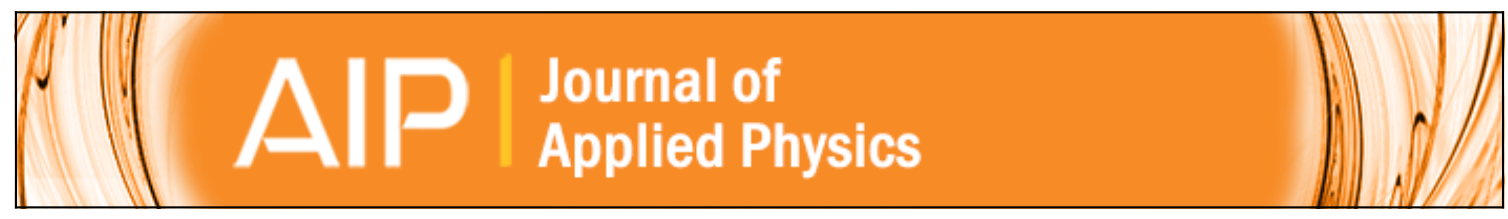

\section{The formation of ternary compound $\mathrm{Fe} 3 \mathrm{Mo} 3 \mathrm{C}$ by ball milling}

L. M. Di, A. Calka, Z. L. Li, and J. S. Williams

Citation: Journal of Applied Physics 78, 4118 (1995); doi: 10.1063/1.360705

View online: http://dx.doi.org/10.1063/1.360705

View Table of Contents: http://scitation.aip.org/content/aip/journal/jap/78/6?ver=pdfcov

Published by the AIP Publishing

\section{Articles you may be interested in}

Magnetism and Sound Velocities of Iron Carbide (Fe3C) under Pressure

Chin. J. Chem. Phys. 27, 297 (2014); 10.1063/1674-0068/27/03/297-301

Significant disorder-induced enhancement of the magnetization of $\mathrm{Fe} 2 \mathrm{CrGa}$ by ball milling

J. Appl. Phys. 114, 013903 (2013); 10.1063/1.4812380

First principles calculation of finite temperature magnetism in $\mathrm{Fe}$ and $\mathrm{Fe} 3 \mathrm{C}$

J. Appl. Phys. 109, 07E138 (2011); 10.1063/1.3562218

Magnetic and Electronic Properties of Nanocrystalline Fe2B and Fe3C Compounds

AIP Conf. Proc. 899, 777 (2007); 10.1063/1.2733518

Nanocomposite formation in the Fe304Zn system by reaction milling

J. Appl. Phys. 75, 5864 (1994); 10.1063/1.355543

\section{A|P| Journal of}

Journal of Applied Physics is pleased to announce André Anders as its new Editor-in-Chief 


\title{
The formation of ternary compound $\mathrm{Fe}_{3} \mathrm{Mo}_{3} \mathrm{C}$ by ball milling
}

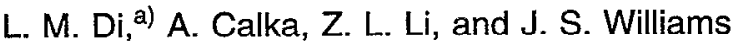 \\ Department of Electronic Materials Engineering, Research School of Physical Sciences and Engineering, \\ The Australian National University, Canberra ACT 0200, Australia
}

(Received 21 December 1994; accepted for publication 20 May 1995)

Ball milling of Mo in nitrogen and ammonia gases has been studied. After heating, the formation of an intriguing ternary compound, $\mathrm{Fe}_{3} \mathrm{Mo}_{3} \mathrm{C}_{1-x}$, was observed as a result of $\mathrm{Fe}$ (and $\mathrm{C}$ ) contamination from the milling apparatus. For a comparison, mechanical alloying of $\mathrm{Fe}-\mathrm{Mo}-\mathrm{C}$ powders with a stoichiometric composition of $\mathrm{Fe}_{3} \mathrm{Mo}_{3} \mathrm{C}$ was also performed and again an $\mathrm{Fe}-\mathrm{Mo}-\mathrm{C}$ alloy was obtained after milling. Thermal analysis shows a single transition peak for the formation of both the $\mathrm{Fe}_{3} \mathrm{Mo}_{3} \mathrm{C}$ phase in the latter case and also for $\mathrm{Fe}_{3} \mathrm{Mo}_{3} \mathrm{C}_{1-x}$ formed as a result of contamination from the mill. The lattice parameter for the $\mathrm{Fe}_{3} \mathrm{Mo}_{3} \mathrm{C}_{1-x}$ phase obtained by Mo-gas reaction is smaller than for the $\mathrm{Fe}_{3} \mathrm{Mo}_{3} \mathrm{C}$ phase obtained by mechanical alloying of stoichiometric $\mathrm{Fe}-\mathrm{Mo}-\mathrm{C}$ powders. It is suggested that, in the $\mathrm{Fe}_{3} \mathrm{Mo}_{3} \mathrm{C}_{1-x}$ phase produced by milling of $\mathrm{Mo}$ in gases, a high concentration of $\mathrm{C}$ vacancies exists. $\mathrm{C} 1995$ American Institute of Physics.

\section{INTRODUCTION}

Mechanical ball milling was first used in the late 1960s and early 1970 s by Benjamin, Volin, and Bomford ${ }^{1-3}$ for the development of dispersion-strengthened $\mathrm{Ni}$ and $\mathrm{Al}$ base superalloys. Many ball milling studies have been performed over the last 10 years, in particular, to produce a wide range of metastable (often disordered) phases. First, atomic disorder of intermetallic compounds was observed in the early stage of ball milling. ${ }^{45}$ Second, amorphous alloys can be obtained by ball milling either elemental powders (mechanical alloying) $)^{6,7}$ or intermetallic compounds (mechanical grinding). ${ }^{8,9}$ In the mechanical alloying (MA) process, the driving force was considered to be the gain of free energy by alloying the elements, while nucleation of crystalline intermetallic compounds with an even lower free energy was kinetically suppressed. In the mechanical grinding (MG) process, atomic disorder was shown to be the major source of energy storage. ${ }^{4,5}$ In some systems phase formation of solid solutions which exist in the phase diagram only at high temperature have also been found after room-temperature mechanical milling. ${ }^{10.11}$ Finally, a mechanically induced phase transformation from a low-temperature crystalline phase to a complex high-temperature phase has been observed. . $^{12,13}$

Recently, many commercially interesting hard materials such as metallic and metalloid nitrides and carbides have been synthesized by the ball milling method. ${ }^{14-16}$ The initial purpose of the present research was to prepare molybdenum nitride by solid-gas reaction during ball milling. Pure nitrogen and ammonia gases were used for the nitrogen sources. However, during the experiment, iron (and carbon) contamination from the milling environment was found to give rise to an intriguing ternary compound $\mathrm{Fe}_{3} \mathrm{Mo}_{3} \mathrm{C}$ in the end milling product. This ternary compound is a interesting material, especially when it exists together with Mo, thus forming a composite material. The results of the ball milling of Mo in nitrogen and ammonia gases are presented in this article. For a comparison, mechanical alloying of $\mathrm{Fe}-\mathrm{Mo}-\mathrm{C}$ powders

${ }^{a)}$ Electronic mail: eme@rsphysse.anu.edu.au with a stoichiometric composition of $\mathrm{Fe}_{3} \mathrm{Mo}_{3} \mathrm{C}$ was also performed.

\section{EXPERIMENTAL PROCEDURE}

Ball milling experiments were performed using a homebuilt planar-type milling device. ${ }^{17}$ The device consists of a few hardened steel balls confined in a horizontal stainlesssteel cylinder cell with $13 \mathrm{~cm}$ inner diameter. In the present experiments, four balls with a diameter of $2.5 \mathrm{~cm}$ were used. An external magnetic field was used to control the ball movement. For the solid-gas reaction, $5 \mathrm{~g}$ of pure molybdenum powder with a purity of $99.95 \%$ and particle size about $150 \mu \mathrm{m}$ was charged in the stainless-steel cell. About 300 $\mathrm{kPa}$ of purified nitrogen or ammonia gas was sealed in the cell. The milling time was about $200 \mathrm{~h}$. For mechanical alloying of $\mathrm{Fe}-\mathrm{Mo}-\mathrm{C}$ powders, $5 \mathrm{~g}$ of pure molybdenum, iron (purity better than $99 \%$ and particle size about $75 \mu \mathrm{m}$ ), and graphite (purity better than $99.9 \%$ and particle size about 50 $\mu \mathrm{m})$ powders with a stoichiometric composition of $\mathrm{Fe}_{3} \mathrm{Mo}_{3} \mathrm{C}$ were used in the same device and milled for $194 \mathrm{~h}$. The system was prepumped and then sealed.

$\mathrm{X}$-ray-diffraction patterns were taken at room temperature by means of a Philips vertical powder diffractometer with $\mathrm{Co} K \alpha$ radiation. Thermal analysis was performed in a Shimadzu DTA-50 thermal analyzer. Chemical analysis for C was performed in the Automatic Carlo Erba 1106 analyzer. The sample is combusted, and the gases, after scrubbing and reducing, arc separated on a gas chromatograph column and measured at the detector.

Energy-dispersive $\mathrm{x}$-ray analysis for $\mathrm{Fe}$ and Mo determination was carried out on a JEOL JSM 6400 scanning electron microscope (SEM) and microscopic structure of the samples was observed in a Cambridge Instruments S360 SEM fitted with a high-brightness lanthanum hexaboride $\left(\mathrm{LaB}_{6}\right)$ electron source. Mössbauer spectroscopy at room temperature, using a $\mathrm{Rh}^{57}$ Co source, was used to examine the annealed samples. Transmission electron microscopy (TEM) was also performed using a JEOL $2000 \mathrm{EX}$ instrument. 


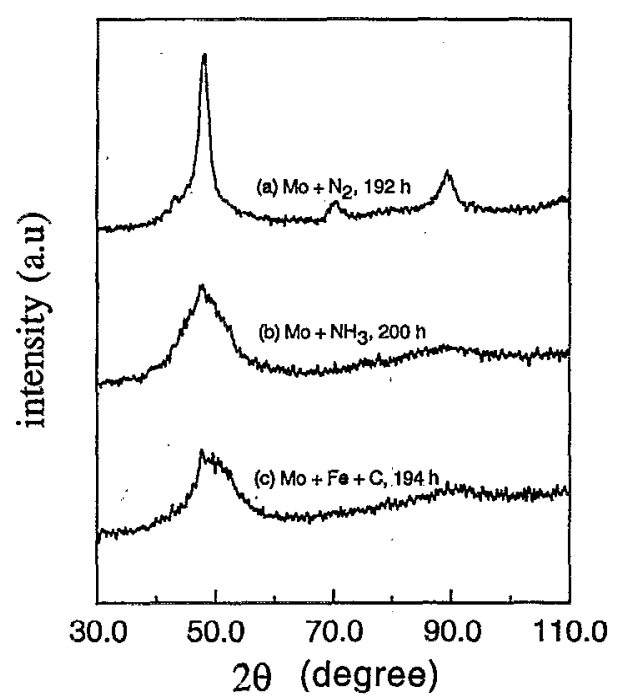

FIG. 1. X-ray-diffraction patterns for (a) Mo milled in $N_{2}$ for $192 h_{2}$ (b) Mo milled in $\mathrm{NH}_{3}$ for $200 \mathrm{~h}$, and (c) $\mathrm{Mo}, \mathrm{Fe}$, and $\mathrm{C}$ powders milled in vacuum for $194 \mathrm{~h}$.

\section{RESULTS}

Three experiments have been performed in the present studies:

(1) Mo powder milled in nitrogen gas for $192 \mathrm{~h}$;

(2) Mo powder milled in ammonia gas for $200 \mathrm{~h}$;

(3) $\mathrm{Mo}, \mathrm{Fe}$, and $\mathrm{C}$ powders mechanical alloyed in vacuum for $194 \mathrm{~h}$.

Figure 1 shows the $x$-ray-diffraction patterns of the materials prepared in the above three experiments. For Mo milled in $\mathrm{N}_{2}$, the $\mathrm{x}$-ray-diffraction patterns still show Mo crystalline peaks. The position of the peaks, however, shifts to high angle, suggesting that there is an absorption of $\mathrm{N}$ in Mo. For Mo milled in $\mathrm{NH}_{3}$, amorphouslike diffraction peaks can be seen. The mechanical alloying of $\mathrm{Mo}, \mathrm{Fe}$, and $\mathrm{C}$ gives similar amorphouslike diffraction patterns. However, a preliminary TEM observation indicates crystalline diffractions

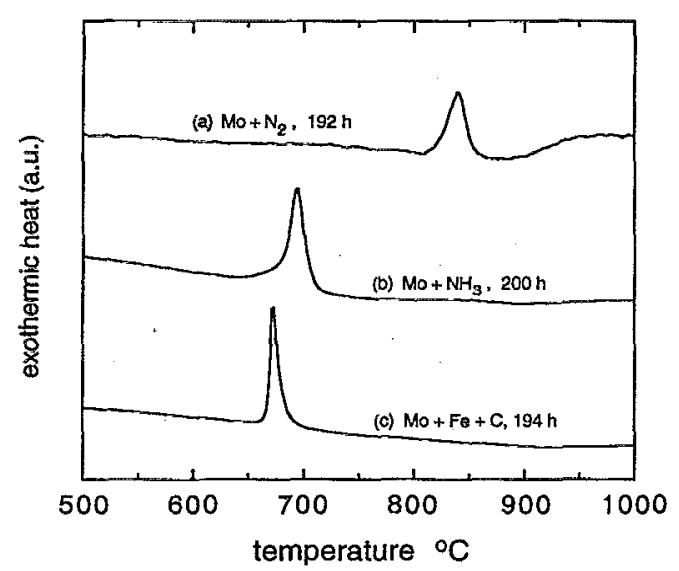

FIG. 2. DTA scans for samples: (a) Mo milled in $\mathrm{N}_{2}$ for $192 \mathrm{~h}$; (b) Mo milled in $\mathrm{NH}_{3}$ for $200 \mathrm{~h}$; and (c) $\mathrm{Mo}$, Fe, and $\mathrm{C}$ powders milled in vacuum for $194 \mathrm{~h}$. The heating rate is $20^{\circ} \mathrm{C} / \mathrm{min}$.

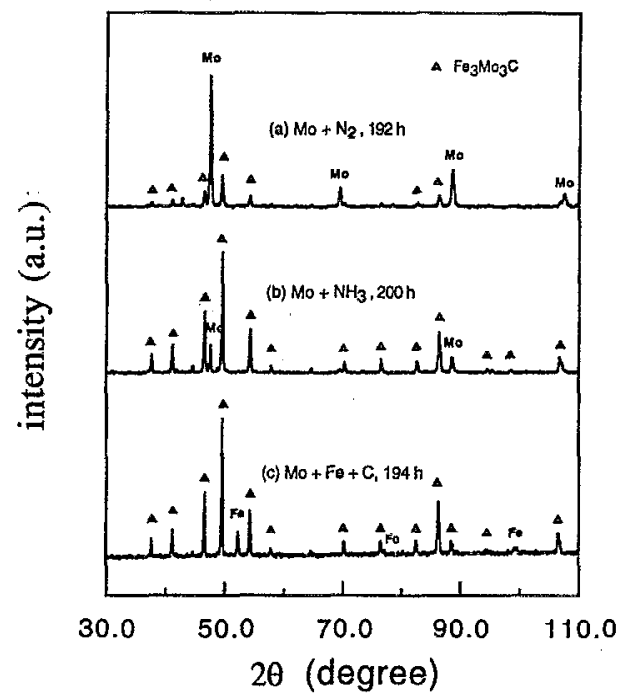

FIG. 3. X-ray-diffraction patterns for (a) Mo milled in $\mathrm{N}_{2}$ for $192 \mathrm{~h}$, (b) Mo milled in $\mathrm{NH}_{3}$ for $200 \mathrm{~h}$, and (c) $\mathrm{Mo}$, $\mathrm{Fe}$, and $\mathrm{C}$ powders milled in vacuum for $194 \mathrm{~h}$ and subsequently heated in DTA up to $1000^{\circ} \mathrm{C}$.

for both of these milled samples. This suggests that the elements have been mixed during milling to form very small crystals of a composite material, which results in amorphouslike diffractions in the $\mathrm{X}$-ray patterns.

Results of the heating of the above three as-milled samples in DTA are given in Fig. 2 for a heating rate of $20^{\circ} \mathrm{C} / \mathrm{min}$. For all three experiments, the heating of milled samples gives a single exothermic peak, which can be identified as the formation of a ternary compound $\mathrm{Fe}_{3} \mathrm{Mo}_{3} \mathrm{C}$ by

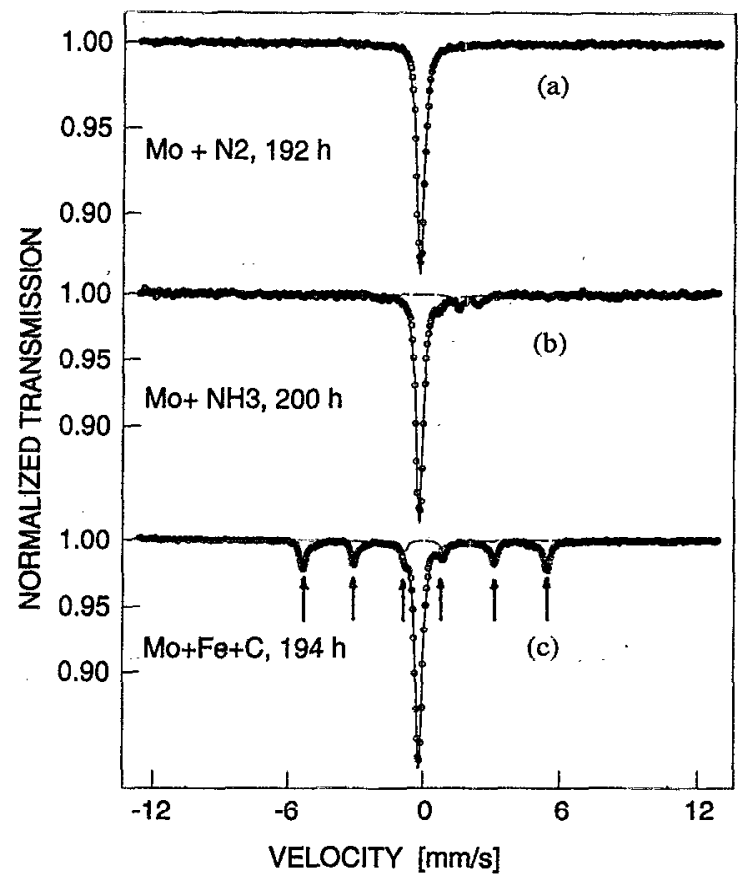

FIG. 4. Room temperature Mössbauer spectra for the three as-milled samples after heating to $1000^{\circ} \mathrm{C}$ in DTA: (a) Mo milled in $\mathrm{N}_{2}$ for $192 \mathrm{~h}$; (b) Mo milled in $\mathrm{NH}_{3}$ for $200 \mathrm{~h}$; and (c) $\mathrm{Mo}, \mathrm{Fe}$, and $\mathrm{C}$ powders milled in vacuum for $194 \mathrm{~h}$. The six-line spectrum shown by arrows is $\alpha$-Fe. 

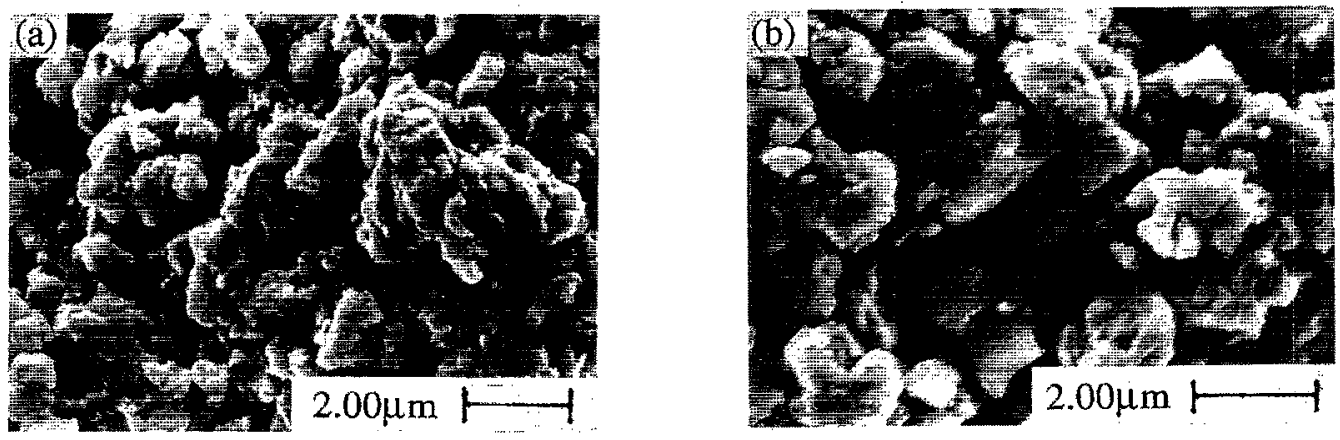

FIG. 5. SEM observations for powders of Mo milled in $\mathrm{N}_{2}$ for $192 \mathrm{~h}$ : (a) as milled; (b) heated in DTA to $1000^{\circ} \mathrm{C}$.

examining the materials before the transition peak and after the transition peak by $x$ rays; however, the peak temperature and heat of the phase formation are different, depending on the method of preparation. The peak temperatures are $840^{\circ} \mathrm{C}$ for Mo milled in $\mathrm{N}_{2}, 695^{\circ} \mathrm{C}$ for Mo milled in $\mathrm{NH}_{3}$, and $675^{\circ} \mathrm{C}$ for mechanical alloying of $\mathrm{Mo}, \mathrm{Fe}$, and $\mathrm{C}$ powders. The phase formation heats are $29 \mathrm{~J} / \mathrm{g}$ for Mo milled in $\mathrm{N}_{2}, 49$ $\mathrm{J} / \mathrm{g}$ for Mo milled in $\mathrm{NH}_{3}$, and $67 \mathrm{~J} / \mathrm{g}$ for mechanical alloying of $\mathrm{Mo}, \mathrm{Fe}$, and $\mathrm{C}$ powders.

$\mathrm{X}$-ray-diffraction patterns have been taken for each of the milled samples after heating in DTA up to $1000^{\circ} \mathrm{C}$. The results are shown in Fig. 3. From Fig. 3 it can be seen that for Mo milled in $\mathrm{N}_{2}$, the Mo peaks become sharper, indicating the growth of Mo crystallites. Moreover, some new peaks appear, which can be identified as originating from the $\mathrm{Fe}_{3} \mathrm{Mo}_{3} \mathrm{C}$ phase. The intensities of $\mathrm{Fe}_{3} \mathrm{Mo}_{3} \mathrm{C}$ diffraction peaks are much smaller than Mo peaks, suggesting that there is only a minor amount of the $\mathrm{Fe}_{3} \mathrm{Mo}_{3} \mathrm{C}$ phase. For Mo milled in $\mathrm{NH}_{3}$, the $\mathrm{x}$-ray-diffraction patterns are similar to those of Mo milled in $\mathrm{N}_{2}$. The only difference is that the relative intensity of the $\mathrm{Fe}_{3} \mathrm{Mo}_{3} \mathrm{C}$ diffraction peaks compared to Mo peaks is higher than in the case of Mo milled in $\mathrm{N}_{2}$. For mechanical alloying of $\mathrm{Mo}, \mathrm{Fe}$, and $\mathrm{C}$ powders, $\mathrm{x}$-ray diffraction shows the major $\mathrm{Fe}_{3} \mathrm{Mo}_{3} \mathrm{C}$ diffraction peaks with smaller Fe peaks.

The room-temperature Mössbauer spectra for the threeas-milled samples after heating to $1000^{\circ} \mathrm{C}$ in DTA are given in Fig. 4. From the bottom curve of Fig. 4, corresponding to the mechanical alloying of $\mathrm{Mo}, \mathrm{Fe}$, and $\mathrm{C}$ powders, the six- line spectrum, as shown (arrowed) in the figure, is characteristic of $\alpha$-Fe. In addition, a dominant single line in the nearleft-hand-side of center is also observed. From the x-raydiffraction patterns in Fig. 3(c) it is believed that the $\mathrm{Fe}_{3} \mathrm{Mo}_{3} \mathrm{C}$ compound is the dominant phase in this material. Therefore, the single dominant line in the Mössbauer spectrum presented in Fig. 4(c) is believed to be the signal from the $\mathrm{Fe}_{3} \mathrm{Mo}_{3} \mathrm{C}$ phase. The middle curve in Fig. 4, for Mo milled in $\mathrm{NH}_{3}$ and heated to $1000^{\circ} \mathrm{C}$ shows no $\alpha$-Fe spectrum. Besides the major line of the $\mathrm{Fe}_{3} \mathrm{Mo}_{3} \mathrm{C}$ phase, some other small peaks may originate from the mixture of $\mathrm{Fe}-\mathrm{Mo}$. For Mo milled in $\mathrm{N}_{2}$ the Mössbauer spectrum (top curve in Fig. 4) shows clearly only the $\mathrm{Fe}_{3} \mathrm{Mo}_{3} \mathrm{C}$ phase, which suggests that in this sample all $\mathrm{Fe}$ impurity has formed the $\mathrm{Fe}_{3} \mathrm{Mo}_{3} \mathrm{C}$ phase. This result is in good agreement with the $x$-ray-diffraction data shown in Fig. 3(a), where only $\mathrm{Fe}_{3} \mathrm{Mo}_{3} \mathrm{C}$ and pure Mo diffractions have been observed.

Figures 5, 6, and 7 give SEM observations for all three ball-milled samples and also for the samples after heating to $1000^{\circ} \mathrm{C}$. From Figs. 5, 6, and 7 both particle size and morphology can be observed. For Mo milled in $\mathrm{N}_{2}$, the particle size after milling is less than $1 \mu \mathrm{m}$ [Fig. 5(a)], and grows to about $1-2 \mu \mathrm{m}$ after heating to $1000^{\circ} \mathrm{C}$ [Fig. 5(b)]. However, for the samples of Mo milled in $\mathrm{NH}_{3}$ and mechanical alloying of $\mathrm{Mo}, \mathrm{Fe}$, and $\mathrm{C}$ powders, the particle size after milling is quite large, and is about $2-5 \mu \mathrm{m}$ [Figs. 6(a) and 7(a)]. Moreover, after annealing the particle size becomes smaller in both latter samples [Figs. 6(b) and 7(b)].

Chemical analysis shows that $0.1 \mathrm{wt} \% \mathrm{C}$ is present in
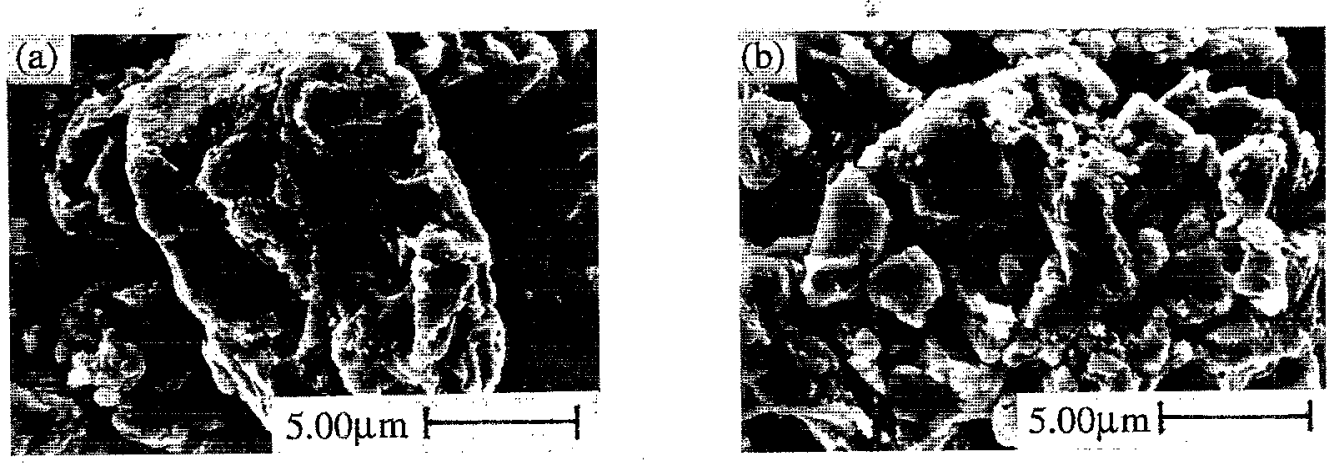

FIG. 6. SEM observations for powders of Mo milled in $\mathrm{NH}_{3}$ for $200 \mathrm{~h}$ : (a) as milled; (b) heated in DTA to $1000^{\circ} \mathrm{C}$. 

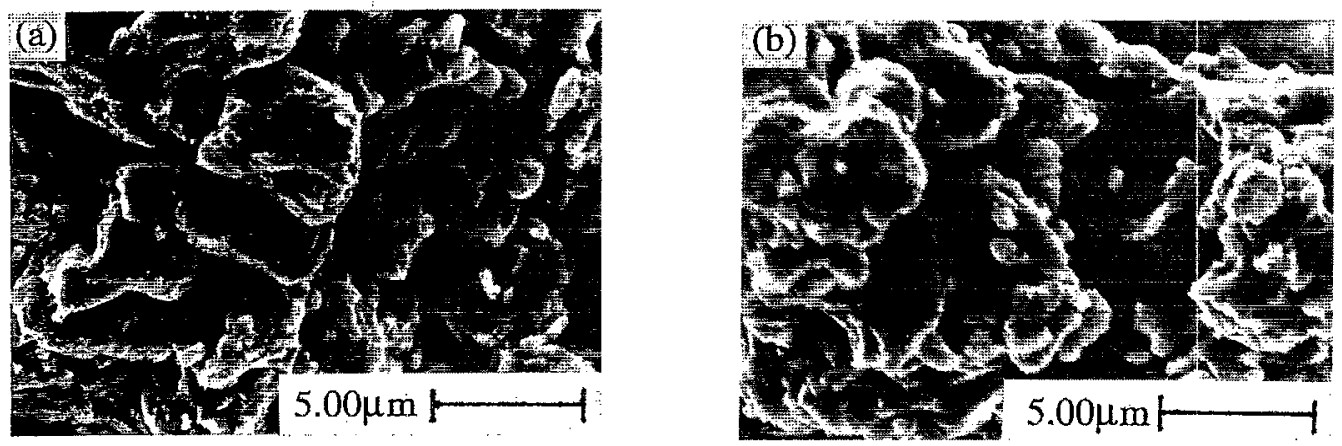

FIG. 7. SEM observations for samples of Mo, Fe, and C powders milled in vacuum for $194 \mathrm{~h}$ : (a) as-milled; (b) heated in DTA to $1000{ }^{\circ} \mathrm{C}$.

the Mo milled in $\mathrm{N}_{2}$ powder, $0.4 \mathrm{wt} \% \mathrm{C}$ in the Mo milled in $\mathrm{NH}_{3}$ powder, and $2.2 \mathrm{wt} \% \mathrm{C}$ in the mechanical alloyed Mo$\mathrm{Fe}-\mathrm{C}$ powder. Furthermore, the elemental analysis for $\mathrm{Fe}$ and Mo carried out in the SEM shows 83 wt $\%$ Mo and 17 wt $\% \mathrm{Fe}$ in the sample of Mo milled in $\mathrm{N}_{2}, 69 \mathrm{wt} \% \mathrm{Mo}$ and 31 wt \% Fe in Mo milled in $\mathrm{NH}_{3}$, and 56 wt \% Mo and 44 wt $\% \mathrm{Fe}$ in mechanical alloyed $\mathrm{Fe}-\mathrm{Mo}-\mathrm{C}$ powder. In this case, $\mathrm{C}$ is neglected and the compositions of $\mathrm{Fe}+\mathrm{Mo}$ are normalized to $100 \%$.

The lattice parameters calculated from the $\mathrm{x}$-ray diffraction patterns in Fig. 3 for the $\mathrm{Fe}_{3} \mathrm{Mo}_{3} \mathrm{C}$ phase are $11.077 \AA$ for samples of Mo milled in both $\mathrm{N}_{2}$ and $\mathrm{NH}_{3}$ and $11.094 \AA$ for the mechanical alloyed $\mathrm{Fe}-\mathrm{Mo}-\mathrm{C}$ sample.

\section{DISCUSSION}

In Fig. 1 the bottom curve, mechanical alloying of $\mathrm{Fe}-$ Mo-C alloy, exhibits an amorphouslike diffraction pattern, where a large amount iron is present in the material (at least $35.8 \mathrm{wt} \% \mathrm{Fe}$ ). The middle curve-Mo milled in $\mathrm{NH}_{3}-$-also shows a similar amorphouslike diffraction pattern, indicating that a considerable amount of iron from the mill has contaminated the material. An Fe-Mo-C composite alloy is formed after milling for these two samples. In contrast, for Mo milled in $\mathrm{N}_{2}$ (top curve in Fig. 1), x-ray-diffraction patterns show only broadened Mo diffraction peaks. This probably means that the iron contamination in the case of milling Mo in $\mathrm{N}_{2}$ is small. The x-ray-diffraction patterns of the asmilled powders after heating to $1000^{\circ} \mathrm{C}$ (Fig. 3) are consistent with this conclusion, because the relative intensity of the $\mathrm{Fe}_{3} \mathrm{Mo}_{3} \mathrm{C}$ phase in Fig. 3(a) is smaller than in Fig. 3(b). Suppose in the annealed $\mathrm{Fe}-\mathrm{Mo}-\mathrm{C}$ alloy, all the carbon has formed the $\mathrm{Fe}_{3} \mathrm{Mo}_{3} \mathrm{C}$ phase, then $2.2 \mathrm{wt} \% \mathrm{C}$ from the chemical analysis gives a concentration of the $\mathrm{Fe}_{3} \mathrm{Mo}_{3} \mathrm{C}$ phase of $85 \mathrm{wt} \%$. In the bottom curve of Fig. 3, pure $\alpha$-Fe diffraction peaks have also been observed. This extra Fe content in the material may again come from contamination during milling. Using a similar calculation method, 0.4 wt $\% \mathrm{C}$ gives an $\mathrm{Fe}_{3} \mathrm{Mo}_{3} \mathrm{C}$ content of $15 \mathrm{wt} \%$ for the material of Mo milled in $\mathrm{NH}_{3}$, and 0.1 wt $\% \mathrm{C}$ gives an $\mathrm{Fe}_{3} \mathrm{Mo}_{3} \mathrm{C}$ content of 4 wt $\%$ for the powder of Mo milled in $\mathrm{N}_{2}$.

The above calculated amounts of the $\mathrm{Fe}_{3} \mathrm{Mo}_{3} \mathrm{C}$ phase seem to be too low in terms of the amounts expected from the upper two curves in Fig. 3, where the intensity of $\mathrm{Fe}_{3} \mathrm{Mo}_{3} \mathrm{C}$ diffraction peaks is not so small; However, because the apparent relative intensity of $\mathrm{x}$-ray-diffraction peaks is not a reliable measure of the relative amount of the phase present, the above estimates may still be valid. On the other hand, if all the $\mathrm{Fe}$ and $\mathrm{C}$ in the $\mathrm{Fe}_{3} \mathrm{Mo}_{3} \mathrm{C}$ phase comes from the milling apparatus, according to the formula of $\mathrm{Fe}_{3} \mathrm{C}$, the $\mathrm{C}$ content in the steel should be $6.8 \mathrm{wt} \%$; which is much more than the actual value of $1 \mathrm{wt} \%$. This suggests that the $\mathrm{Fe}$ content in the milled powders is considerably in excess of that necessary to form the $\mathrm{Fe}_{3} \mathrm{Mo}_{3} \mathrm{C}$ phase.

From the elemental analysis for $\mathrm{Fe}$ and Mo performed in the SEM, the amount of $\mathrm{Fe}_{3} \mathrm{Mo}_{3} \mathrm{C}$ phase can also be estimated. The results are: $49 \%$ of the $\mathrm{Fe}_{3} \mathrm{Mo}_{3} \mathrm{C}$ phase in the sample of Mo milled in $\mathrm{N}_{2}, 87 \%$ of the $\mathrm{Fe}_{3} \mathrm{Mo}_{3} \mathrm{C}$ phase in the sample of $\mathrm{Mo}$ milled in $\mathrm{NH}_{3}$, and $91 \%$ of the $\mathrm{Fe}_{3} \mathrm{Mo}_{3} \mathrm{C}$ phase in the sample of mechanical alloyed $\mathrm{Fe}-\mathrm{Mo}-\mathrm{C}$ alloy.

The amounts of the $\mathrm{Fe}_{3} \mathrm{Mo}_{3} \mathrm{C}$ phase calculated from the measured $\mathrm{C}$ content and from measured $\mathrm{Fe}$ and Mo contents are very different. An explanation for the above discrepancy may be that, in the $\mathrm{Fe}_{3} \mathrm{Mo}_{3} \mathrm{C}$ phase formed by contamination of $\mathrm{Fe}$ and $\mathrm{C}$ from the milling apparatus, the $\mathrm{C}$ content is less than the stoichiometric composition, i.e., $\mathrm{Fe}_{3} \mathrm{Mo}_{3} \mathrm{C}_{1-x}$; however, the $\mathrm{Fe}_{3} \mathrm{Mo}_{3} \mathrm{C}_{1-x}$ phase is in the same cubic structure as stoichiometric $\mathrm{Fe}_{3} \mathrm{Mo}_{3} \mathrm{C}$. It may be that a high concentration of $\mathrm{C}$ vacancies exists in the milled materials, where the $\mathrm{Fe}_{3} \mathrm{Mo}_{3} \mathrm{C}$ phase was formed by $\mathrm{Fe}$ and $\mathrm{C}$ from contamination. The lattice parameters calculated from the $\mathrm{X}$-ray diffractions in Fig. 3 for $\mathrm{Fe}_{3} \mathrm{Mo}_{3} \mathrm{C}_{1-x}$ phase produced by different methods give support for the above speculation. In fact, the lattice parameter for both the $\mathrm{Fe}_{3} \mathrm{Mo}_{3} \mathrm{C}_{1-x}$ phase produced by Mo milled in $\mathrm{N}_{2}$ and that produced in $\mathrm{NH}_{3}$ is smaller than that for the $\mathrm{Fe}_{3} \mathrm{Mo}_{3} \mathrm{C}$ phase obtained by mechanical alloying of $\mathrm{Fe}-\mathrm{Mo}-\mathrm{C}$ powder, consistent with the notion of $\mathrm{C}$ vacancies. In addition, the amount of $\mathrm{Fe}_{3} \mathrm{Mo}_{3} \mathrm{C}$ phase estimated from the $\mathrm{Fe}$ and $\mathrm{Mo}$ analysis, and the consequential $\mathrm{C}$ content, is also consistent with this picture. In principle, there should be $2.4 \mathrm{wt} \% \mathrm{C}$ present in mechanical alloyed $\mathrm{Fe}-$ Mo-C powder, which is very close to the actual value of 2.2 wt $\%$ obtained by chemical analysis. Thus, the $\mathrm{Fe}_{3} \mathrm{Mo}_{3} \mathrm{C}$ compound obtained by mechanical alloying of stoichiometric $\mathrm{Fe}-\mathrm{Mo}-\mathrm{C}$ powders and heated in the DTA up to $1000{ }^{\circ} \mathrm{C}$ contains few $\mathrm{C}$ vacancies. However, for Mo powder milled in $\mathrm{N}_{2}$ and in $\mathrm{NH}_{3}$, the measured $\mathrm{C}$ contents are very small, much less than that required for the stoichiometric $\mathrm{Fe}_{3} \mathrm{Mo}_{3} \mathrm{C}$. Assuming $\mathrm{C}$ vacancies, we obtain compositions of 
$\mathrm{Fe}_{3} \mathrm{Mo}_{3} \mathrm{C}_{1-0.9}$ and $\mathrm{Fe}_{3} \mathrm{Mo}_{3} \mathrm{C}_{1-0.8}$ for samples of Mo milled in $\mathrm{N}_{2}$ and $\mathrm{NH}_{3}$, respectively.

In Fig: 2, the single exothermic peak for all three samples is indicative of $\mathrm{Fe}_{3} \mathrm{Mo}_{3} \mathrm{C}$ phase formation, as shown by $\mathrm{x}$-ray diffraction. Therefore, the differences in phase transformation temperatures and heats of formation shown in Fig. 2 can be related either to the amount of $\mathrm{Fe}_{3} \mathrm{Mo}_{3} \mathrm{C}$ phase or to different compositions and/or grain sizes present in the as-milled $\mathrm{Fe}-\mathrm{Mo}-\mathrm{C}$ composite alloy. The data obtained in this study on composition, structure, and thermal behavior indicate that the phase transformation on annealing is complex and it is difficult to separate the various contributions from each other.

The SEM results and also the $x$-ray data indicate the growth of Mo particle size after heating of the powder produced by milling Mo in $\mathrm{N}_{2}$. Figures 6 and 7, however, suggest a decrease of the particle size after heating the samples of Mo milled in $\mathrm{NH}_{3}$ and mechanical alloyed $\mathrm{Fe}-\mathrm{Mo}-\mathrm{C}$ powders. This is probably a result of the different phases present in the materials before and after heating. For both Mo milled in $\mathrm{NH}_{3}$ and mechanical alloyed $\mathrm{Fe}-\mathrm{Mo}-\mathrm{C}$ powders, an $\mathrm{Fe}-\mathrm{Mo}-\mathrm{C}$ composite alloy is present after milling, and this transforms to the $\mathrm{Fe}_{3} \mathrm{Mo}_{3} \mathrm{C}$ phase after heating. Apparently the particle size for the $\mathrm{Fe}_{3} \mathrm{Mo}_{3} \mathrm{C}$ phase is very fine.

\section{v. CONCLUSIONS}

A Fe-Mo-C composite alloy is obtained by mechanical alloying of $\mathrm{Fe}, \mathrm{Mo}$, and $\mathrm{C}$ elemental powders. Subsequent heating in DTA to $1000^{\circ} \mathrm{C}$ shows the formation of the $\mathrm{Fe}_{3} \mathrm{Mo}_{3} \mathrm{C}$ ternary compound. About $9 \mathrm{wt} \% \mathrm{Fe}$ is also observed and this excess $\mathrm{Fe}$ originates from the milling apparatus. The lattice parameter for such $\mathrm{Fe}_{3} \mathrm{Mo}_{3} \mathrm{C}$ phase is $11.094 \AA$.

For mechanical milling of $\mathrm{Mo}$ in $\mathrm{N}_{2}$ and in $\mathrm{NH}_{3}$ gases, $\mathrm{Fe}$ (and $\mathrm{C}$ ) contamination from the milling device is observed. $17 \mathrm{wt} \% \mathrm{Fe}$ is found in the powder of Mo milled in $\mathrm{N}_{2}$ and $31 \mathrm{wt} \% \mathrm{Fe}$ is found in the powder of Mo milled in $\mathrm{NH}_{3}$. After heating in the DTA apparatus up to $1000^{\circ} \mathrm{C}$, the formation of the compound $\mathrm{Fe}_{3} \mathrm{Mo}_{3} \mathrm{C}_{1-x}$ is also observed in both samples. However, the $\mathrm{C}$ content obtained by chemical analysis is very small and we propose a high concentration of $\mathrm{C}$ vacancies in such samples. Moreover, the lattice param- eter for $\mathrm{Fe}_{3} \mathrm{Mo}_{3} \mathrm{C}_{1-x}$ phase in both samples is $11.077 \AA$. The smaller lattice parameter for the $\mathrm{Fe}_{3} \mathrm{Mo}_{3} \mathrm{C}_{1-x}$ phase in samples of Mo milled in gases is consistent with the presence of $\mathrm{C}$ vacancies.

Finally, the present work illustrates the strong driving force for the formation of an $\mathrm{Fe}_{3} \mathrm{Mo}_{3} \mathrm{C}_{1-x}$ ternary compound in competition with competing nitriding reaction. A further interesting aspect of the present work is the different, apparently stable composition (carbon content) of the end product. Mechanical testing of these different phases would be illuminating. Further work will concentrate on the study of the mechanical properties of such intriguing materials.

\section{ACKNOWLEDGMENTS}

The authors wish to acknowledge G. M. Wang for the measurement of the Mössbauer spectra, R. Chao and R. Bergman for the chemical analysis of $\mathrm{C}, \mathrm{D}$. Vowles for the elemental analysis of $\mathrm{Fe}$ and Mo, R. Heady for the SEM observations, and David Llewellyn for TEM observations. This research has been carried out on behalf of the Harry Triguboff AM Research Syndicate.

${ }^{1}$ J. S. Benjamin, Metall. Trans. 1, 2943 (1970).

${ }^{2}$ J. S. Benjamin and T. E. Volin, Metall. Trans. 5, 1929 (197.4).

${ }^{3}$ J. S. Benjamin and M. J. Bomford, Metall. Trans. 8, 1301 (1977).

${ }^{4}$ L. M. Di, P. I. Loeff, and H. Bakker, J. Less-Common Met. 168, 183 (1991).

${ }^{5}$ L. M. Di, H. Bakker, Y. Tamminga, and F. R. de Boer, Phys. Rev. B 44, 2444 (1991).

${ }^{6}$ C. C. Koch, O. B. Cavin, C. G. McKamey, and J. O. Scarbrough, Appl. Phys. Lett. 42, 1017 (1983).

${ }^{7}$ T. J. Tiainen and R. B. Schwarz, J. Less-Common Met. 140, 99 (1988).

${ }^{8}$ L. M. Di, P. I. Loeff, and H. Bakker, Phys. Status Solidi 117, K99 (1990).

${ }^{9}$ A. Ye. Yermakow, Ye. Ye. Yurchikov, and V. A. Barinov, Phys. Met. Metall. 52, 50 (1981).

${ }^{10}$ L. M. Di and H. Bakker, J. Phys: Condensed Matter 3, 3427 (1991).

${ }^{11}$ L. M. Di, H. Bakker, P. Bárczy, and Z. Gácsi, Acta Metall. Mater. 41, 2923 (1993).

${ }^{12}$ L. M. Di, G. F. Zhou, and H. Bakker, Phys. Rev. B 47, 4890 (1993).

${ }^{13}$ G. F. Zhou, L. M. Di, and H. Bakker, J. Appl. Phys. 73, 1521 (1993).

${ }^{14}$ A. Calka and J. S. Williams, Mater. Sci. Forum 88-90, 787 (1992).

${ }^{15}$ W. Y. Lim, M. Hida, A. Sakakibara, Y. Takemoto, and S. Yokomizo, J. Matcr. Sci. 28, 3463 (1993).

${ }^{16}$ A. Calka, J. I. Nikolov, and B. W. Ninham, in Proceedings of the 2nd International Conference on Structure, Applications of Mechanical Alloying, Vancouver, British Columbia, Canada, 1993, p. 189.

${ }^{17}$ A. Calka and A. P. Radlinski, Mater. Sci. Eng. A 134, 1350 (1991). 